\title{
Risk Management Analysis In Iman Santoso's Tax Consultant
}

\author{
$1^{\text {st }}$ Dwi Septi Haryani \\ Management Department \\ STIE Pembangunan \\ Tanjungpinang \\ Tanjungpinang, Indonesia \\ dwiseptih@stie- \\ pembangunan.ac.id
}

\author{
$2^{\text {nd }}$ Muhammad Rizki \\ Management Department \\ STIE Pembangunan \\ Tanjungpinang \\ Tanjungpinang, Indonesia \\ m.rizki@stie-pembangunan.ac.id
}

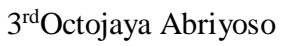 \\ Management Department \\ STIE Pembangunan \\ Tanjungpinang \\ Tanjungpinang, Indonesia \\ octojaya@stie- \\ pembangunan.ac.id
}

\author{
$4^{\text {th }}$ Eka Kurnia Saputra \\ Management Department \\ STIE Pembangunan \\ Tanjungpinang \\ Tanjungpinang, Indonesia \\ ekakurnia@stie- \\ pembangunan.ac.id
}

\begin{abstract}
Along with the development of the business world, many new regulations have been issued. This is also applied in the field of taxation. Generally, the public as tax payers do not understand about the general conditions of taxation. This situation made worse with frequent changes of regulation from the Minister of Finance in the field of taxation. Thus, the service of the tax consultant is needed in this situation. The purpose of this research is analyzing and identifying the risks that occur, and finding out the action that can be done to avoid, prevent and minimize the risks that can occur in Drs. Iman Santoso's tax consultant. The approach used in this research is qualitative descriptive approach. The research is located in Delima Street, Pinang Mas Blok F no. 1 \& 2. Data collection techniques used in this research are interviews, observation and documentation. The results showed from 6 relevant risks there are 1 risk that is classified as extreme risk, 4 risks classified as medium risk and 1 risk as low risk. In addition, the tax consultant should do preventive measures based on priority of highest risk in order to reduce and avoid unwanted risks.
\end{abstract}

\section{Keywords-Tax Consultant, Risk Management}

\section{INTRODUCTION}

The public as tax payers in general do not really understand about the general conditions of taxation. This is due to their educational background. In addition, large number of new rules, regulations and an increasingly difficult business conditions make tax payers tend to focus on business and prefer not to take any risks in handling the tax issues. Thus, the tax payers require persons or organizations that are able to handle their tax issues; in this case the service tax consultant is needed. The role of tax consultant is to facilitate tax payers in meeting their taxation obligations.

The increase in complexity in terms of taxation regulation and business conditions may have an impact, especially in terms of risks. In general, any activity that is performed, whether it is by individuals or companies, certainly has risk [1]. For example, operational risks such as work accidents, human error, product failure and etc. This is a thing that should be taken into account by any company. This means that the companies have to estimate the risk that will be facing as well as trying try to anticipate it. This can also happen to a tax consultant that is facing a dynamic business conditions.

Tax consultant is a profession that is run by a professional who understands about the field of taxation and provide services in fulfilling the rights and obligations of the tax payer. Services that are able to meet the client's needs anytime, anywhere and in any condition quickly and appropriately is the key to the success of a tax consultant. Tax consultant has the ideal role in helping the Directorate General of Taxes in educating tax payers in society. One of the existing tax consultants in Tanjungpinang is Drs. Iman Santoso's tax consultant.

Drs. Iman Santoso's tax consultant has provided its services as a taxation and financial accounting consultant since 2002 in Tanjungpinang. The organization services including making tax reports for individual and organizations, annual financial reports, etc. The financial reports includes monthly and annual reports consisting of income statement, balance sheet, and capital changes reports, etc.

Thus, this research is done with the aims to:

1. To analyze the risks that occurs in Drs. Iman Santoso's tax consultant.

2. To find out the impact occurred from the risks that happens in Drs. Iman Santoso's tax consultant.

3. To find out the actions that needs to be done as a form of anticipation and prevention of the risks and its impact.

\section{LITERATURE REVIEW}

\section{A. Risk Management}

Risk understanding according to the Oxford Dictionary (2005) is a situation involving exposure to danger [2]. While, Fadun (2013), risk is commonly associated with uncertainty, as the event may or may not occur [1]. The risk is generally known as the something negative, like loss, danger, and other consequences. There are several definitions of risk such as [3]:

a. Risk is the chance of loss. Chance of loss is usually used to indicate a situation where there is an openness (exposure) against loss or a possible loss. 
b. Risk is the possibility of loss. Possibility of loss means that the probability of an event is something between zero and one.

c. Risk is uncertainty. Risk is uncertainty means that risk appears because of the uncertainty. Uncertainty is a potential change that will occur in the future as a consequence of the inability to know what will happen, when an activity is done at this time, Chapman et al (2003) confirms that it is very important Placing uncertainty (uncertainty) as a starting point in risk management [4].

Risk management does not eliminate risks, but manages risks associated with firms' operations, thereby maximizes opportunities and minimizes threats [5]. Risk management aims to manage risk so that we can obtain the most optimal results [1]. One of the implementation of risk management in the company known is Enterprise Risk Management (ERM) [6].

Lam (2000) defines ERM as an integrated framework for managing operational risk, credit risk, market risk, economic capital, and risk transfer to maximize constant value [7]. According to the Committee of Sponsoring Organizations of the Treadway Commission (COSO) defines Enterprise Risk Management (ERM) as a process, influenced by the board of Directors, management and other personnel, applied in the regulatory strategies and in the company, designed to identify potential events that may affect the entity, and manage risk at its risk, to provide reasonable assurance regarding the achievement of entity objectives [8]. While Darmawi (2016), Enterprise Risk Management (ERM) is an organization that requires a system and efficient administrative procedures, as well as effective [9].

Risk management is essentially done through the following processes [10]:

a. Risk Identification. This process involves identifying the risks that may occur in a business activity. Accurate and complete risk identification is vital in risk management [11].

b. Evaluation and risk measurement. Hanafi (2014), the purpose of the risk evaluation is to understand the characteristics of the risk better [1]. Risk measurement is to do calculations or judgments on the impacts of the identified risks, the small impact of risk will be categorized, which is the risk with a major risks, which has a large and widespread impact that require management or not (minor risks), which does not require special handling because the level of risk is within acceptable limits [4].

c. Risk Mitigation. After analysis and evaluation of risks, the next step is manage risk. The risks should be managed. If organization fail to manage risks, the consequences are received can be quite serious, such a great loss [10]. The risk can be managed in various way, such as avoidance, retention, diversification, or to transferred to other parties [10].

Related studies supporting this study include the research conducted by 1) [1] entitled "The Analysis Of Potato Chips Product Damaged Risk In Widuri Joint Venture Group", the results showed that there are several factors that can cause the failure of the production process and the product itself which was an error in the selection of raw materials, skipping the process of soaking potatoes, a mistake in the provision of lime paste, errors at controlling stove fire, and human error that have impact on the organization. 2) [6] entitled "Risk Analysis The Failure of Oyster Mushroom Cultivation On Bintan Cendawan", the results showed that there are several factors that can cause failure in the process of oyster mushroom cultivation, these factors consist of several levels so that the impact caused also has a scale or level of which can often occur until that never happens and also has a high or low impact. 3) [12], entitled "Application Of Enterprise Risk Management In Order To Improve The Effectiveness Of Operational Activities CV. Anugrah Berkat Calindojaya”, the findings of this study indicate that there are 21 risks in the company. Risks that should be paid attention by the company are the risks that the handling is not yet appropriate which will give bad impact to the company.

\section{B. Tax Consultant}

According to the regulation from finance minister of the republic Indonesia No.111/PMK.03/2014 about tax consultant, the definition of the tax consultant is a person who provides tax consulting services to tax payers in order to fill the right and duty according to the regulations [13].

\section{RESEARCH METHODOLOGY}

This research is done by using qualitative method. The data was collected through interviews and observation. In qualitative research there are four ways of data collection techniques (Trianto, 2010), namely participant observation, indepth interviews, documentation studies, and the third combination is called triangulation [14]. In this study, authors use trianggulation techniques to ensure that the data obtained is valid using interviews and observations. This research consists of primary and secondary data. Primary data obtained through interviews, while secondary data obtained through internal data of Iman Santoso's Tax Consultant.

The sampling technique used in this study was purposive sampling technique where the selected respondent has the knowledge, skills, and competencies in the areas examined. The respondent in this research is 1 person, which is the operational manager of Iman Santoso's tax consultant.

\section{RESULT AND DISCUSSIONS}

\section{A. Tax Consultant Work Procedures}

To maintain a well-balanced relationship between tax consultant and their clients, it is necessary for both parties to make an agreement before the start of the services. Generally, the consultants will issue an offer letter in providing Financial Services as well as Tax Services. Below is the procedure of how a tax consultant usually works, which consists of:

1) Receiving financial related data or inputs from the clients and then proceed to sort which data is related to taxation to be calculated.

2) Calculating account posts which are subjected to tax.

3) Issuing payment notes for clients' tax. 
4) Issuing ID Billing through SSE.

5) Tax Payment through Bank.

6) Inputting e-SPT according to conditions and prerequisites.

7) Filling Tax Report either manually to the Tax Office or through websites.

\section{B. Risk That Can Occur}

There are no activities or jobs that are free from risks, this includes the business of Tax Consultants. Various possibilities can occur and exhibit a risk in doing the activity or work procedures from tax consultant. These risks include:

1) Error In Posting. Error in Posting can occur due to the lack of data given by the client to the consultant. In this case it could results in either Overpaid or Lesspaid tax.

2) Error in Tax Calculation. Error in calculating taxes can occur due to imprecision of the staffs in calculating the tax and errors in categorizing which type of tax are they supposed to be paid with.

3) Error in Issuing ID Billing. Error in Issuing ID Billing can occur due to the inaccuracy of the staff that fills in the type of deposit account code, the number of tax objects, the nominal amount or tax that must be paid up through SSE.

4) Delays in Tax Payment and Tax Filling. Delays in Tax Payment and Tax Filling can occur due to the resistance of the error in posting, error in calculation, or even the lack of data provided by the client so that the consultant could not issue a payment note in time.

5) System Interference from the Directorate General of Taxes Server. System Interference from Directorate General of Taxes Server usually occurs due to a significant number of visitors in payment and filling through websites so the server from TDG frequently crashes and cannot be accessed.

6) Weather Factor. Weather Factor may cause interference with the internet or power outages that can delay the work processes of tax consultant where connection could be lost.

\section{Impact of Occurred Risks}

The impact that can occurred from those risks includes:

1) Administration Sanctions. From the risk of Error in posting which directly related to payment and filling taxes, then from the tax office will issue a letter of Tax Bills with the administrative sanctions based on rules which had been set.

2) Fined Interest. If there is any interference in posting and calculation, then it will also related to the tax payment. Tax Payment that does not fit a predetermined schedule will be subject to a fined interest.

Based on the above explanation, to make it easier for the author in conducting a discussion and then to draw conclusions, the authors make a risk identification table of work procedures by counting the frequency of how often the occurrence and the extent of the impact caused.
The frequency are labelled from 1 to 5 :

$$
\begin{array}{ll}
1 & \text { : Never } \\
2 & \text { : Rarely } \\
3 & \text { : Quite Often } \\
4 & \text { : Often } \\
5 & \text { : Very Often }
\end{array}
$$

While the impacts are also labelled from 1 to 5 :

\begin{tabular}{|c|c|c|c|}
\hline \multicolumn{2}{|r|}{ TABLE I. } & \multicolumn{2}{|c|}{ ISK IDENTIFICATION } \\
\hline No. & $\begin{array}{c}\text { Risk } \\
\text { Identification }\end{array}$ & Frequency & Impact \\
\hline $\mathrm{R} 1$ & Error In Posting & 2 & 3 \\
\hline $\mathrm{R} 2$ & $\begin{array}{c}\text { Error In Tax } \\
\text { Calculation }\end{array}$ & 3 & 3 \\
\hline R3 & $\begin{array}{l}\text { Error in Issuing } \\
\text { ID Billing }\end{array}$ & 2 & 3 \\
\hline $\mathrm{R} 4$ & $\begin{array}{l}\text { Delays in Tax } \\
\text { Payment and } \\
\text { Filling }\end{array}$ & 2 & 4 \\
\hline R5 & $\begin{array}{c}\text { System } \\
\text { Interference from } \\
\text { the Directorate } \\
\text { General of Taxes } \\
\text { Server }\end{array}$ & 4 & 4 \\
\hline R6 & Weather's Factor & 2 & 2 \\
\hline
\end{tabular}

$$
\begin{array}{ll}
1 & \text { : Very Small } \\
2 & : \text { Small } \\
3 & : \text { Medium } \\
4 & : \text { High } \\
5 & \text { : Extreme }
\end{array}
$$

The following is the table that contains the identification of risks and their frequency of occurrence and their impact on Drs. Iman Santoso's tax consultant.

After getting the results of the identification of risks and their frequency of occurrence and the impact caused, then to be able to see and find out whether the risk is a risk with a low severity, Moderate severity, and high severity, the researchers do a combination between the frequency of occurrence of the risk and impact of those risks in a matrix with the $\mathrm{x}$ and $\mathrm{y}$ axis in the matrix such as risk management which is also known as likelihood - impact matrix.

This matrix aims to make it easier for the company to let them conduct anticipation action or prevention with risk with high severity will receive a major concern which must be anticipated and prevented first.

\section{TABLE II. I LIKELIHOOD-IMPACT MATRIX}

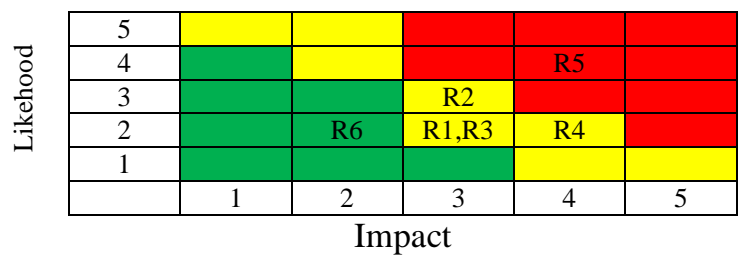

Below are some explanations about the matrix above: 
1) Each box in green means that the risks are on the low severity.

2) Yellow Boxes means that the risks are on the medium severity.

3) While Red Box means that the risk is high in severity.

Based on the above matrix it can also be noted that the:

1) R1 (Error in Posting) is the risk with moderate severity. This means that the impact caused is not too severe and not too large. This occurs in the frequency with which categorized as rarely. However, if the risk occurs then it will not bring any major impact.

2) R2 (Error in Tax Calculation) is the risk with moderate severity. This means that the impact caused is not too severe and not too large. This occurs in the frequency with which categorized as quite often. But if it occurs then it will not give too big of an impact.

3) R3 (Error in Issuing ID Billing) is the risk with moderate severity. This occurs in a rare frequency and if it occurs, the impact caused is not too large.

4) R4 (Delays in Tax Payment and Filling) is the risk with a high severity, frequency of occurrence is rare but if it occurs it will bring a big impact.

5) R5 (System Interference from the Directorate General of Taxes Server) is the risk with a high severity, frequency of occurrence is categorized often and the impact arise if occurred is also high.

6) R6 (Weather's Factor) is the risk with low severity. This occurs in a rare frequency, but if it happens it will not bring too big of an impact.

\section{Risk Mitigation}

Based on the risks that exists then risk management that can be done are as follows:

1) R1 (Error in Posting). Treatment for error in posting risk is to reduce risk. Action that can be done regarding error in posting is to give a notice to the client regarding the data that should be sent on a regular basis and do a reconfirmation over data that has been received in order to prevent any lack of data that is sent to be posted.

2) R2 (Error in Tax Calculation). Treatment for those risks is to reduce risk. Solution that can be done is to implant supervision from Supervisor or Team Leader prior to issuing ID Billing

3) R3 (Error in Issuing ID Billing). Treatment for those risks is to avoid risk. Solution that can be done regarding error in issuing ID billing is to do double check before proceeding to print.

4) R4 (Delays in Tax Payment and Filling). Treatment for those risks is to avoid risk. Solution that can be done regarding delays in tax payment and filling is to implement supervision from Supervisor or Team Leader before either uploading the report to the website or reporting manually at tax office. In addition, it can also be done with a notice on a regular basis to remind the client a few days before the tax payment and filling date.

5) R5 (System Interference in Tax Payment and Filling). Treatment for those risks is to accept the risk. Solutions that can be done is to inform the frequent problem that occur in their system to the Tax Directorate General, and do Tax Payment and Filling manually to the bank and tax office.

6) R6 (Weather's Factor). Treatment for those risks is to avoid risk. Solutions that can be done is to buy a UPS so that when the electricity is off suddenly, the computer that is used for work is not suddenly off which will provide time for employees to save inworking data and files.

Based on the resultof this research, the authors provide recommendations or suggestions as follows:

1) Drs. Iman Santoso's Tax Consultant should conduct a supervision and re-checking twice or double check by a Supervisor or Team Leader if the work has been done by an Accounting Staff to prevent any unwanted risks.

2) Always do a re-confirm with the client on a regular basis so as not to have a miss communication over the requested data and data sent.

\section{ACKNOWLEDGMENT}

The authors thanked below parties that had been helpful in completing this research, i.e.:

1) Ms. Sulili as the Operational Manager in Drs. Iman Santoso's Tax Consultant.

2) Andrian and team who helped the authors to get the data in Drs. Iman Santoso's Tax Consultant.

\section{REFERENCES}

[1] D. S. Haryani, I. Ilyas, Satriadi, and S. Fauzar, "The Analysis Of Potato Chips Product Damaged Risk In Widuri Joint Venture Group," in Proceeding International Seminar on Accounting for Society, 2018, pp. $48-56$.

[2] S. H. Nikou and H. Selamat, "Risk Management Capability within Malaysian Food Supply Chains," Int. J. Agric. Econ. Dev., vol. 1, no. 1, pp. 37-54, 2013.

[3] F. Fauzi, "Manajemen Resiko Di Tengah Perubahan Model Bisnis TelekomunikasI," J. Teknol. Elektro, vol. 8, no. 1, pp. 64-68, 2017.

[4] I. G. A. I. M. Pertiwi, W. S. Kristinayanti, and I. G. M. O. Aryawan, "Manajemen Risiko Proyek Pembangunan Underpass Gatot Subroto Denpasar," J. Akuntansi, Ekon. dan Manaj. Bisnis, vol. 4, no. 1, pp. 1-6, 2016.

[5] O. S. Fadun, "Risk management and risk management failure: Lessons for business enterprises," Int. J. Acad. Res. Bus. Soc. Sci., vol. 3, no. 2, pp. 225-239, 2013.

[6] D. S. Haryani, “Analisis Risiko Kegagalan Budidaya Jamur Tiram Pada Bintan Cendawan," J. Ekon. dan Bisnis Indones., vol. 04, no. 01, pp. 1-5, 2019.

[7] I. Ahmed and N. A. Manab, "Influence of enterprise risk management 
success factors on firm financial and non-financial Performance: A Proposed Model," Int. J. Econ. Financ. Issues, vol. 6, no. 3, pp. 830-836, 2016.

[8] M. Mustapha and A. Adnan, "A Case Study of Enterprise Risk Management Implementation in Malaysian Construction Companies," Int. J. Econ. Financ. Issues, vol. 5, no. 2, pp. 70-76, 2015.

[9] D. S. Haryani and Risnawati, "Analisis Risiko Operasional Berdasarkan Pendekatan Enterprise Risk Management (Erm) Pada Pt. Swakarya Indah Busana Tanjungpinang," J. Dimens., vol. 7, no. 2, pp. 357-367, 2018.

[10]M. M. Hanafi, Manajemen Risiko, 2nd ed. Yogyakarta: UPP STIM YKPN, 2014.

[11]A. N. Rilyani, Y. Firdaus, and D. D. Jatmiko, "Analisis Risiko Teknologi Informasi Berbasis Risk Management Menggunakan ISO 31000 (Studi Kasus : i-Gracias Telkom University)," e-Proceeding Eng., vol. 2, no. 2. pp. 6201-6208, 2015.

[12]Mellisa and F. A. Andono, "Penerapan Enterprise Risk Management Dalam Rangka Meningkatkan Efektifitas Kegiatan Operasional ' $\mathrm{Cv}$. Anugerah Berkat Calindojaya," Calyptra J. Ilm. Mhs. Univ. Surabaya, vol. 2, no. 1, 2013.

[13]D. Katuuk, H. Manossoh, and H. Manossoh, "Pengaruh Integritas Dan Kreativitas Konsultan Pajak Terhadap Kepatuhan Wajib Pajak," J. Ris. Akunt. Going Concern, vol. 12, no. 2, pp. 1-8, 2017.

[14]Z. Munawwaroh, "Analisis Manajemen Risiko Pada Pelaksanaan Program Pendidikan Dalam Upaya Meningkatkan Mutu Pendidikan," $J$. Adm. Pendidik., vol. XXIV, no. 2, pp. 71-79, 2017. 